\title{
Lockheed Martin And The Controversial F-35
}

Michael P. Hughes, Francis Marion University, USA

\begin{abstract}
Over the course several years - from late in the 1950s to the early 1970s - Lockheed was embroiled in the "Deal of the Century" where the company was found guilty of bribing foreign countries' governments to select the Lockheed F-104 Starfighter over arguably better alternatives in addressing those nations' respective air force needs. Today, Lockheed Martin is the leading contractor on the F-35 Lightning II project, which is intended to produce the world's most advanced stealth strike-fighter for US armed forces and those of several allied foreign nations. However, the F-35 program has become the single most expensive project in American history and has been beset with serious technical problems, major schedule delays, cost overruns, and the F-35's performance capabilities are seen by many as inferior to the nation's potential adversaries' fighter aircraft, if not inferior to the aircraft it is intended to replace.
\end{abstract}

Keywords: Defense Contracts; Government Contracts; Finance; Corruption; Scandal; Management

In the councils of government, we must guard against the acquisition of unwarranted influence, whether sought or unsought, by the military-industrial complex. (President Dwight D. Eisenhower)

\section{INTRODUCTION}

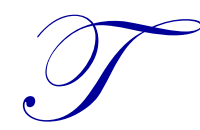

he military-industrial complex is a relationship that exists between the nation's military and the industrial sector that produces the weapons and associated equipment required by the military to defend the American nation and pursue the national policy goals set forth by the president. One of the key advantages the American military has enjoyed, especially since World War II, has been its technology and production capabilities. Indeed, it was just such advantages that came to the forefront during World War II and, to a large extent, made victory by the Allied nations possible against savvy and technologically advanced adversaries. In fact, America became a major supplier of not only weapons and support equipment for US armed forces, but also for the armed forces of most allied nations. The might of the American industrial sector made this possible; hence, due credit must be given to American industry for its part in America's wartime victories.

The Lockheed Corporation, and later the Lockheed Martin Corporation, ${ }^{1}$ is and has been an integral part of supplying the American nation and many of its allies with advanced aircraft and weapons systems. It is a storied company with many notable achievements, but it also has been at the center of at least a few major controversies. Over the course of several years - from the late 1950s to the early 1970s - Lockheed was embroiled in the "Deal of the Century" scandal where the company bribed several foreign countries' governments to select the Lockheed F104 Starfighter over arguably better alternatives in addressing those nations' respective air force needs. Today, Lockheed Martin is the leading contractor on the F-35 Lightning II project, which is intended to produce the world's most advanced stealth strike-fighter for US Armed forces and several allied foreign nations. The F-35 program has become the single most expensive project in the nation's history. It has been beset with serious technical problems, major schedule delays, cost overruns, and the F-35's performance capabilities are seen by many as inferior to the nation's potential adversaries' fighter aircraft, if not inferior to the aircraft it is intended to replace.

\footnotetext{
${ }^{1}$ The Lockheed Corporation merged with Martin Marietta in 1995 to form the Lockheed Martin Corporation.
} 


\section{THE HISTORY}

In 1912, brothers Allan and Malcom Loughead started the Alco Hydro-Aeroplane Company in San Francisco, California. They renamed the company Loughead Aircraft Manufacturing Company in 1916 and subsequently moved the company to Santa Barbara, California. A brilliant young draftsman, by the name of Jack Northrup, joined the company in that same year. ${ }^{2}$ The company produced a flying boat which was met with some success. Later, the company designed a new highly-advanced monocoque airplane - the S-1. ${ }^{3}$ Unfortunately, the company put this new airplane on the market in the immediate post-World War I years when the market was flooded with surplus military aircraft that could be purchased for pennies on the dollar. Unable to compete price-wise in this saturated market, Loughead Aircraft Manufacturing Company went out of business in 1921.

Five years later - in 1926 - Allan Loughead, Jack Northrup, and Kenneth Jay teamed up and opened a new aircraft company. This time they named the company Lockheed Aircraft Company, which is the phonetic spelling of Allan Loughead's last name. Their first product, designed by Jack Northrup and Gerard Vultee, ${ }^{4}$ was the Lockheed Vega. This was a single-engined, high-wing monoplane in which many records were set by such notable pilots as Wiley Post, who flew a Vega around the world twice, and Amelia Earhart who was the first woman to fly solo across the Atlantic Ocean.

During the 1930s, Lockheed designed and produced the Model 10 Electra which was a small two-engined transport or passenger aircraft, depending on configuration. This is the aircraft that, in 1937, Amelia Earhart attempted her around-the-world flight and then disappeared somewhere over the Pacific Ocean after taking off from Lae, New Guinea. No trace was ever found of her, her navigator, or their airplane. Also during these years, the company produced the Model 12 Electra Junior and the Model 14 Super Electra.

In 1937, not long before the onset of World War II, Lockheed designed and began production of the Hudson - a light bomber and a further development of the Model 14 Super Electra. In addition to US military sales, many of these aircraft were sold to foreign nations, most notably to the British Royal Air Force (RAF) and the Japanese Imperial Army. This airplane was used primarily in the coastal recognizance and submarine hunting roles.

Also in 1937, Lockheed began the design of the immortal P-38 Lightning and by 1940 the first of these fine fighter aircraft began to roll off the assembly line. The P-38 was designed by one of the world's all-time greatest aircraft designers - Clarence "Kelly" Johnson. Johnson's design was a twin-engined, mid-wing, dual-boom fighter, which was a quite unusual design for an era when most contemporary fighters were single-engined, low-wing designs. The P-38 was responsible for more enemy aircraft shot down during World War II than any other American fighter. While the P-38 was used mostly in the Pacific theater against the Japanese, it did see service in Europe against the Germans and Italians. The Germans called it the "fork-tailed devil", which was an epithet of respect from the enemy. The two highest scoring fighter aces in US history achieved their victories while flying the P-38 in the Pacific Theater. Those aces were US Army Air Force (USAAF) ${ }^{5}$ pilots Richard "Dick" Bong, with 40 victories, and Pete McGuire, with 38 victories. The P-38 also gained fame during the war as the aircraft that shot down and killed the commander of the Combined Fleet of the Japanese Imperial Navy and the architect of the Japanese attack on Pearl Harbor - Admiral Isoroku Yamamoto. Admiral Yamamoto was being transported in a Mitsubishi GM4 "Betty" bomber to a remote Japanese naval airbase in the Solomon Islands for an inspection when

\footnotetext{
${ }^{2}$ Jack Northrup would later go on to start his own aircraft company which has figured prominently in the American defense industry. The most expensive airplane in the world, the B-2 Spirit stealth bomber, was designed and is produced by the Northrup Grumman Corporation. Northrup Grumman is the result of the 1994 merger of Northrup and Grumman aircraft companies.

${ }^{3}$ A monocoque aircraft design is one where the skin of the airplane serves as the primary structure, as opposed to the then common separate wood or steel tube aircraft structures which in turn were covered with doped fabric, wood, or aluminum sheeting. The difference in these aircraft structures is much like comparing the structure of an insect with that of a mammal. The outer covering - or "skin" - of an insect also serves as its skeleton, whereas a mammal has a separate internal skeleton and an outer covering or skin - the insect has an exoskeleton, which means it has a monocoque structure. Virtually all modern aircraft have monocoque structures.

${ }^{4}$ Gerard Vultee would later go on to form his own aircraft company producing several World War II aircraft designs for the US Navy and then, after the war, merging with the Consolidate Aircraft Company to form Convair. Convair produced such notable aircraft as the F-102 Delta Dagger, F-106 Delta Dart, the B-36 Peacemaker, and the F-16 Fighting Falcon under the General Dynamics name. General Dynamics would eventually be acquired by the Lockheed Corporation in 1993, essentially bringing Vultee back to the Lockheed fold.

${ }^{5}$ The US Army Air Force preceded the US Air Force, which did not become a separate service until 1947.
} 
he was shot down. The loss of Admiral Yamamoto represented a major loss for the Japanese war machine. The P38 was the only fighter aircraft produced by the US that was used from the beginning to the end of American involvement in the war.

In 1939, Lockheed decided to enter the large airline and air transport aircraft business by developing the Model 49 Excalibur on its own. This was Lockheed's first foray into these types of aircraft. The Model 49 design evolved to eventually become the L049 Constellation - or "Connie" - as most knew it. ${ }^{6}$ The lead engineer on this project was, again, Kelly Johnson. The Connie's design used a scaled-up wing from the P-38 Lightning, had four powerful Wright R-3350 radial engines, a swoopy flat S-shaped fuselage, and a distinctive triple tail. This airplane was a thing of pure beauty, but with the onset of World War II airline travel was being curtailed and it was looking like the Connie might be stillborn. Then the eccentric multi-millionaire - Howard Hughes ${ }^{7}$ - stepped in and saved the Connie. Hughes lent Lockheed the cash to proceed with building the airplane. Howard Hughes was the major stockholder and president of Trans World Airlines (TWA) ${ }^{8}$ and, being the man with the money, he essentially dictated the specifications he wanted Lockheed to redesign the airplane to. ${ }^{9}$ Lockheed markedly exceeded the minimum requirements in these specifications and delivered Hughes a truly superior airplane which went on to be adopted by the USAAF as a military transport in the form of the C-69 and later an improved version was adopted by the US Air Force (USAF) as the C-121. In post-war airline service, the Connie was continually updated to stay ahead of the competition and it remained the most advanced piston engine-powered airliner in the world. It stayed in frontline US and major foreign airline service well into the 1960s and secondary airline and the freight business into the 1970s. Only in the face of the arguably more cost-effective jet airliner did the mighty Connie finally succumb.

In 1954, Lockheed's venerable C-130 Hercules - an immensely useful four-engined, turboprop cargocarrying airplane took to the skies for the first time. The C-130 "Herky Bird" (aka "Trash Hauler") is capable of operating from unprepared air fields and is used as a cargo and troop transport aircraft, as a gunship in support of ground forces, in supporting medical evacuations and humanitarian relief operations, in search and rescue operations, in supporting scientific and weather research, as an aerial refueling aircraft, as a firefighter, and in numerous other roles. This highly versatile airplane is used by military and civilian operators all over the world and has been in continuous production for longer than any other military airplane in history. It remains in frontline service with many militaries around the world, including the US armed forces.

In 1963 Lockheed followed the immortal C-130 with a heavy-lift, transcontinental cargo airplane - the C141 Starlifter. This was a four-engine, turbofan-powered airplane capable of carrying very large amounts of cargo and troops to operating locations throughout the world. It remained in frontline service with the USAF until 2006 when it was replaced by Boeing's C-17 Globemaster III. In 1969, the USAF began operating Lockheed's enormous cargo airplane - the C-5 Galaxy. The C-5 was designed to transport extremely large, outsized cargo worldwide. This mega-sized, four-engined turbofan-powered airplane was the largest airplane in the world until the first flight of the Soviet's Antonov AN-124 Ruslan (NATO: Condor) in 1982. The C-5, nonetheless, remains one of the world's largest airplanes. The cargo deck of the C-5 is actually one foot longer than Orville and Wilbur Wright's famous first powered flight at Kitty Hawk in 1903 . The C-5 is still in frontline service with the USAF.

Lockheed sought to follow the Connie's success in the airline aircraft business with their wide-body L1011 TriStar. The TriStar first flew in 1970. This airplane was intended to compete with Boeing's 747 and McDonnell-Douglas' DC-10. The L-1011, like McDonnell-Douglas' DC-10, was a three-engined turbofan powered airplane. Boeing's 747 is powered by four turbofan engines. The L-1011 was not a great success. Boeing's 747 secured the majority of wide-body airliner sales, while the McDonnell-Douglas' DC-10 was only marginally more

\footnotetext{
${ }^{6}$ The Constellation was produced in several models: 049, 649, 749A, 1049G, and 1649A, along with some minor sub-types and an experimental turboprop version - the Navy R7V-2.

${ }^{7}$ Later Howard Hughes would become a billionaire.

${ }^{8}$ TWA was acquired by American Airlines in 2001.

${ }^{9}$ Howard Hughes was an aircraft designer and racer himself, so he understood aircraft design quite well. He started the Hughes Aircraft Company, which was responsible for various notable aircraft and helicopter designs, and a multitude of weapon, missile, and space systems. In fact, the Hughes Air Space and Communication Group is responsible for around 40 percent of all commercial satellites in service. The Hughes helicopter operations are now owned by the Boeing Aircraft Corporation and include such notable products as the OH-6 Cayuse (aka AH-6 Little Bird in special-forces configuration) and the AH-64 Apache attack helicopters.
} 
successful than the L-1011. ${ }^{10}$ With the failure of the L-1011, Lockheed left the airline aircraft production business and concentrated primarily on the national defense business.

Under great secrecy during World War II, Lockheed designed and developed a jet fighter designated the P$80^{11}$ Shooting Star. ${ }^{12}$ The P-80 was developed by a special Lockheed development group referred to as the "Skunk Works." Legend has it that the development group was named after the moonshine factory in the "Li'l Abner" comic strip; the idea being that moonshine was typically distilled in great secrecy - in secret locations. Such secrecy was the nature of the P-80 development. The first P-80s were deployed to Italy just before the end of the war. They only just missed meeting the German jet fighter - the Messerschmitt Me- $262^{13}$ - in combat by a few weeks. The P80, by now redesignated the F-80, did see air-to-air combat in Korea. The F-80 became the first jet fighter to shoot down another jet fighter in combat. In late 1950 an F-80 shot down a Soviet-built Mikoyan-Gurevich MiG-15 in aerial combat, even though by this time the F- 80 was an obsolescent design and markedly inferior to its Soviet-built adversary. From the F-80, Lockheed developed the T-33 Shooting Star. The T-33 served as a high-performance pilot trainer with many nations around the world for several decades until being replaced by the venerable supersonic Northrup T-38 Talon. From the T-33 Lockheed then developed the F-94 Starfire, an interim all-weather fighter interceptor tasked with protecting American airspace against enemy bombers. The F-94 was a stopgap interceptor that helped address the American nation's air defense needs until the advent of Convair's supersonic F102 Delta Dagger.

The highly secretive Skunk Works design group carried on after World War II, headed by chief engineer Kelly Johnson. Such notable aircraft as the F-104 Starfighter interceptor, the U-2 Dragon Lady and SR-71 Blackbird recognizance aircraft, ${ }^{14}$ and the F-117 Nighthawk stealth strike fighter were developed within the realm of the Skunk Works. Of these aircraft, the U-2 remains in frontline service with the USAF.

In 1993, Lockheed purchased the General Dynamics Corporation production division, which placed one of the world's most widely used light multirole fighter aircraft - the F-16 Fighting Falcon - under Lockheed management. The General Dynamic Corporation was itself the result of mergers and acquisitions involving the Holland Torpedo Boat Company, Canadair, and the Convair Company. Convair, in turn, was the result of a merger between the Consolidated and Vultee aircraft companies. Convair produced the F-102 Delta Dagger and F-106 Delta Dart, among America's foremost Cold War fighter-interceptors. Consolidated had manufactured the famous World War II bomber - the B-24 Liberator - the most produced heavy bomber in history.

In March 1995, Lockheed merged with the Martin Marietta Company. Martin-Marietta itself was the result of a 1961 merger between the Glenn L. Martin Company and the American-Marietta Corporation. The Glenn L. Martin Company had produced such notable aircraft as the China Clipper flying boats used by Pan Am World Airways in the 1930s, the PBM Mariner, and the B-26 Marauder of World War II fame - a high-performance twinengine medium bomber. The company also manufactured the Titan missile, which, in its various models, was used as an intercontinental ballistic missile (ICBM) and as one of America's most heavily used space boosters in launching satellites and the manned Gemini spacecraft in the 1960s. Titan-family missiles were used until 2005. The American-Marietta Corporation was a producer of paints, dyes, and metallurgical products.

After the merger of Lockheed and Martin-Marietta, the company was reincorporated as Lockheed Martin and today is one of the largest defense contractors in the world. Lockheed Martin's first major aircraft product was the F-22 Raptor stealth fighter. This is the world's first operational fifth-generation fighter. However, the F-22's high costs curtailed production to 187 aircraft. These high costs were further aggravated by the inability to sell these aircraft to foreign nations due to the prohibitions on the transfer of its technology to foreign entities, with the

\footnotetext{
${ }^{10}$ The McDonnell-Douglas DC-10 was later designated the MD-11 when the McDonnell and Douglas corporations merged. The DC-10/MD-11 is no longer used as an airliner. Today, most of the DC-10/MD-11s are used as cargo carriers and a few as aerial refuelers in the USAF, where they are known as the KC-10 Extender.

${ }^{11}$ The designation P-80 was changed to F-80 when the US Air Force became an independent service in 1947.

${ }^{12}$ Major Richard "Dick" Bong, America's leading fighter ace, was killed while flight testing a P-80 in 1945.

${ }^{13}$ The Messerschmitt Me-262 was the world's first operational jet fighter.

${ }^{14}$ The SR-71 Blackbird is the world's only openly-known air-dependent aircraft capable of cruising at over three times the speed of sound. The SR-71 was retired from frontline US Air Force service in 1999.
} 
corresponding loss of economies of scale. Lockheed Martin's F-35 Lightening II strike fighter is the company's current project. The F-35, in large part, is supposed to address the high cost problem of the F-22 by producing a less expensive airplane that can simultaneously serve as a basic airframe for addressing the USAF's, US Navy's (USN), and the US Marine Corp's (Marines) operational requirements. In actuality, the F-35 has demonstrated itself to be an exceedingly expensive and controversial project and it, along with the F-104's checked past, is discussed later in this paper.

The company, both as Lockheed and Lockheed Martin, has been involved in many other defense and intelligence-oriented developments over the years. These include the AH-56 Cheyenne attack helicopter program, which was not adopted by the US Army; the Polaris, Poseidon, and Trident submarine launched ballistic missiles (SLBM); the previously-mentioned Titan family of missiles; the Agena spacecraft; the Corona satellite; and a host of other systems.

\section{THE PROBLEM}

Even in light of the eminently-successful Constellation and less-than-successful L-1011 TriStar, since the end of World War II, most of the Lockheed's - and, later, Lockheed Martin's - business has been as a defense and government contractor providing cutting edge research, technology development, and the design, development, fielding, and sustainment of many of the world's most advanced weapon, intelligence collecting, and space systems. Like most defense contractors, Lockheed Martin's business is a feast or famine arrangement wholly dependent on securing government contracts, both foreign and domestic. Lockheed Martin's management, as the agent for the company's stockholders, has a fiduciary obligation to those stockholders to maximize their wealth through effective and profitable management of the company. The management also has responsibilities to other stakeholders, such as the company's employees and the communities surrounding major Lockheed Martin facilities. Given the fickle nature of politics and the fact that most government contracts are highly influenced, if not completely driven by politics, the management of a large defense contractor, such as Lockheed Martin, becomes rather challenging. Superior management of the company's financial resources and its risk is crucial to its success, such as ensuring sufficient financial reserves to cover lean profit years (famine years). Also, maintaining a viable and experienced defense industry is seen by government and defense planners as essential to the national defense. This means that several major defense contractors fall into a category of being "too important to national defense" to allow them to fail. This is much on the order of several principal financial institutions being viewed by government as "too big to fail" because of their importance to the financial system of the nation. Even with such government help, however, no company wants the government poking around in its business affairs or directing its operations. Still, being a defense contractor, and therefore a "national resource," the government will impose itself and, to the extent possible, the company must find a way to effectively manage such government "help."

\section{THE SCANDALS}

There have been numerous scandals, alleged or real, surrounding many defense contractors since the founding of the nation and such defense-related scandals are not unique to the US, or even to more recent times. Throughout history, scandals have plagued governments and militaries as well as the industries supporting them. These scandals seem mostly borne from the fickle politics and the sometimes corrupted nature of government contracts, especially those associated with weapon developments in time of war when immediate needs often override more prudent procurement processes. The question is whether or not an alleged scandal is indeed criminal, greedy, unethical, and unpatriotic or is simply the product of astute business practices in a highly-competitive, highstakes business arena.

The F-104 Starfighter - a sleek and impressive looking airplane - was developed as a result of the experiences of the USAF in Korea, especially when flying against the Soviet-built Mikoyan-Gurevich MiG-15 jet fighter. $^{15}$ American fighter pilots were looking for a new fighter that flew higher and faster than the North

\footnotetext{
${ }^{15}$ The MiG-15 was such a shock to the Pentagon when it entered the fray in Korea that it led to an immediate accelerated demand for higher, faster, and a more powerful fighter aircraft to counter the newly reassessed and respected Soviet threat. Cost became a secondary consideration.
} 
American F-86 Sabre that they were flying. ${ }^{16}$ Kelly Johnson commenced the design of a new fighter that would address these requirements. This was also at a time of rapidly advancing technologies, especially in the area of airto-air missiles. These technological developments were thought to make aircraft guns and traditional close-in air-toair combat (i.e., dogfighting) obsolete. ${ }^{17}$ Another basis for fighter design in the early to mid-1950s was the threat of Soviet high-flying, nuclear-armed bombers, so defense of the American airspace was of utmost importance. This led to fighter-interceptor designs ${ }^{18}$ that traded the maneuverability so necessary for close-in dogfights for even higher speed and altitude capabilities. Kelly Johnson's resulting design was the F-104 Starfighter - a Mach 2 fighter-interceptor ${ }^{19}$ - that had exceedingly small wings with very narrow profiles. ${ }^{20}$ The F-104 entered service with the USAF in the Air Defense Command (ADC). ADC, in conjunction with the Canadian Air Force, was tasked with defending American and Canadian airspace under the combined North American Aerospace Defense Command (NORAD). Although the F-104 was designed as an interceptor, it proved itself to be inferior to other ADC fighter interceptors, such as the McDonnell F-101 Voodoo ${ }^{21}$ and the later Convair F-106, which replaced the F-104 in ADC service. The Lockheed F-104 was found lacking in range, endurance, and weapons capability. ${ }^{22}$ The F-104 only stayed in service with ADC for a year. These ADC F-104s were subsequently transferred to various Air National Guard units. A later variant of the F-104 served for a brief period of time with the USAF's Tactical Air Command (TAC) in Vietnam. The F-104 was not any more successful with TAC than it had been with ADC, so its tenure with TAC was short lived.

Lockheed had essentially "bet the farm" on the F-104 and with the USAF not finding great use for the airplane, Lockheed decided to seek foreign buyers. Several allied nations were in need of upgrading their fighter fleets with new technology fighter aircraft. The Cold War was in full swing and the Europeans needed a counter to the new and far more capable Soviet aircraft being fielded by the Warsaw Pact nations, whereas the Japanese also needed a counter air fighter to defend Japanese airspace against Soviet, Communist Chinese, and North Korean threats. Other nations, such as Saudi Arabia, were seeking to modernize their air forces as well. A highly updated variant of the F-104 - known as the Super Starfighter - entered a series of international competitions against several competitors' aircraft, such as the American Grumman F-11F Super Tiger and Convair F-106, the French Dassault Mirage III, the Swedish Saab J-35 Draken, the British English-Electric Lightning, and a few other lesser designs. While the F-104 was shown to be inferior to some of the competing designs in various realms of performance, maintainability, and mission suitability, it was nonetheless selected as the winning aircraft in several nations' supposedly competitive selection processes. The first nation selecting the F-104 as the winner was Japan in 1957. The Japanese Air Self-Defense Force had demonstrated that the Grumman F-11F Super Tiger was the airplane that Japan should buy, yet the F-104 was selected by the Japanese government. Then, in 1961, West Germany likewise selected the Lockheed interceptor over other demonstratively superior fighter entrants. This seemed strange in light of the inferior performance demonstrated by the F-104 during the competitive evaluations and the fact that the USAF had removed the airplane from frontline service after only a brief period of time operating it. Canada was next in line to select the F-104, which was then followed by several other European nations. This whole affair came to be known as the "Deal of the Century."

Investigations into the F-104 selection processes eventually brought to light (in 1976) that Lockheed had paid \$22 million in bribes to foreign officials to select the F-104 over its rivals. Subsequent to this, several foreign officials were prosecuted and found guilty of various crimes in their respective nations. In the US during 1975 and 1976, the US Senate also concluded that Lockheed had paid bribes to members of foreign governments to select the F-104 over the competition. This finding led to the Foreign Corrupt Practices Act (FCPA) outlawing the bribing of foreign officials.

\footnotetext{
${ }^{16}$ Although the F-86 was generally on par with the MiG-15, fighter pilots understandably want something much better than their opponents fly.

${ }^{17}$ The fallacy of these ideas was clearly demonstrated a decade later during America's involvement in Vietnam.

${ }^{18}$ A fighter-interceptor's first requirement is to quickly take off and climb to altitude to intercept enemy aircraft which, in most cases, are bombers.

${ }^{19}$ Mach 1 is the speed of sound, which is approximately 761 miles per hour at sea level during a "standard day." This, of course, means that Mach 2 is twice the speed of sound. Most pistol bullets travel at speeds less than Mach 1.

${ }^{20}$ In fact, the F-104's wing profile is so narrow that the leading edge is actually sharp, requiring special covers to avoid personnel getting injured by the wing's leading edge during ground handling and maintenance of the airplane.

${ }^{21}$ The F-101 was designed and fielded prior to McDonnell merging with the Douglas Aircraft Corporation to form McDonnell-Douglas. The F101 carried the nuclear-tipped Genie intercept rocket designed to destroy entire bomber formations with a single rocket.

${ }^{22}$ The F-104 could not successfully carry and fire the Genie, which was a requirement in those years.
} 
By 1971, Lockheed was deeply in debt, brought about by failed programs such as the L-1011 TriStar airliner and the AH-56 Cheyenne attack helicopter. However, at that time, Lockheed was the largest single US defense contractor and, much like the "too big to fail" concept surrounding the largest financial institutions in the US, Lockheed was seen by many within government as being too critical to national defense to allow the company to fail. So when Lockheed came looking for financial help, the government was only too happy to assist. Amid pronounced congressional dissention, the government provided \$195 million in loan guarantees for the company. Then, just when things looked like they were getting back on track for Lockheed, the FCPA was signed into law. In spite of the loan guarantees, the FCPA nearly bankrupted the company.

In the midst of the F-104 "Deal of the Century", Lockheed was also found culpable in bribing Italian politicians during the negotiation of sales of C-130s to Italy. The Italian investigation into this matter led to the resignation of the Italian president in 1978.

\section{THE F-35}

Lockheed Martin's current aircraft development and production program is the F-35 Lightning II Joint Strike Fighter (JSF), a fifth-generation fighter design. Lockheed Martin has partnered with Northrup-Grumman, Pratt \& Whitney, and British Aerospace (BAE) ${ }^{23}$ in the development and production of the F-35. Each of these companies has specific responsibilities in the program; however, Lockheed Martin remains the primary and lead contractor.

The general JSF program preceded the F-35 program. The JSF program was intended to select a single airplane to replace a broad range of more specialized aircraft currently in service with the USAF, USN, and the Marines. The selected JSF airplane would have to be readily adaptable to whatever mission was required of it. Specifically, the JSF was supposed to be able to serve as an air-to-air fighter, a long-range strike aircraft, and be able to provide close air support to ground forces - all in one airplane. The two leading competitors in the JSF program were Lockheed Martin's X-35 and Boeing's X-32. The X-35 won the competition and this airplane was further developed into the F-35. The USAF, USN, and the Marines are all participants in the F-35 project, as are the air forces of Canada, the United Kingdom, Germany, Italy, the Netherlands, Norway, Denmark, Turkey, Israel, Japan, and Australia. Several other nations are also considering buying the F-35 once it goes operational and demonstrates itself to be cost effective. There are to be three primary models of the F-35: 1) the F-35A for the USAF with conventional takeoff and landing (CTOL), 2) the F-35B for the Marines with short takeoff and vertical landing (STOVL), and 3) the F-35C for the USN as an aircraft carrier-based fighter with catapult capabilities referred to as the "carrier version" (CV). F-35s configured for other nations will be based off one of these three primary models with some customization for the specific nation's defense requirements. There also could be some limitations on the transfer of advanced technologies to some foreign nations, so those aircraft may be somewhat less capable than US versions.

The F-35 is a single-engine, single seat airplane possessing so-called "stealth" capabilities in that it is designed to minimize its radar return; hence, making it less identifiable, if not invisible to enemy radar. It has such features as an internal weapons bay and, in the Marine version, it is capable of short field take-offs with full weapons load and vertical landings. ${ }^{24}$ The US plans on buying 2,443 of these aircraft ${ }^{25}$ for the USAF, USN, and the Marines.

Many claims have been made for the F-35 by Lockheed Martin's development team. In 2006, Lockheed Martin claimed that the F-35 would be "four times more effective" than current fighters in air-to-air combat, "eight times more effective" than current fighters in air-to-ground combat and "three times more effective" than current fighters in recognizance and suppression of an enemy's air defenses. Further, they claimed that F-35 would have

\footnotetext{
${ }^{23}$ BAE was formerly known as English Electric.

${ }^{24}$ The F-35B is capable of both vertical takeoffs and landing, but not with a full weapons load as what would be expected in the combat arena. The idea is that operational F-35Bs will take off using a short field with a full weapons load, expend that weapons load during the mission, and then land vertically upon returning to base.

${ }^{25}$ This number excludes 14 aircraft used for research, development, testing, and evaluation (RDT\&E). When the RDT\&E aircraft are included, the number is 2,457 .
} 
better range and require less logistics support than existing fighters and be the "premier strike aircraft through 2040 and to be second only to the F-22 in air superiority." In turn, the Pentagon states that the F-35 will be "the most affordable, lethal, supportable and survivable aircraft ever to be used."

A key feature in keeping the costs down for the F-35 is that the international partners are supposed to contribute funds for its development and will purchase significant quantities of aircraft, hence making the cost of each airplane much less for all buyers through economies of scale. A potential problem is that if any of the partners pull out of the program, the costs per airplane will likely go up markedly.

The F-35 program has been beset with numerous and major cost overruns. The F-35 program has become what Mark Thompson in Time Magazine calls the "costliest weapons program in human history" (Thompson, 2013). The 2013 Department of Defense Selected Acquisition Report (SAR) ${ }^{26}$ on the F-35 program put the acquisition costs at $\$ 323,493.5$ million in base-year 2102 dollars (Table 1) which, when adjusted for price inflation during the scheduled procurement years, this figure adjusts to $\$ 398,584.6$ million, or nearly $\$ 400$ billion in then-year dollars (Department of Defense, 2013). When maintenance and other support costs are included over the expected life of the program, the costs go much higher. Life cycle cost estimates put the program at $\$ 1.5$ trillion over the 55-year expected program life (Francis, 2013). There are many, however, who think that figure is low.

Table 1 is derived from the 2013 Department of Defense Selected Acquisition Report (SAR) for the F-35 program and presents the total program cost of acquiring the F-35 as calculated in 2013. The Acquisition Program Baseline (APB) figures denote the intended objective and threshold values for cost in base-year (BY) 2012 dollars.

Table 1: Total Acquisition Cost - Total Program

\begin{tabular}{|c|c|c|c|c|}
\hline & \multicolumn{3}{|c|}{ BY2012 \$M } & \multirow{2}{*}{$\begin{array}{c}\text { BY2012 \$M } \\
\text { Current } \\
\text { Estimate }\end{array}$} \\
\hline Appropriation & $\begin{array}{c}\text { SAR Baseline } \\
\text { Dev Est }\end{array}$ & $\begin{array}{r}\mathrm{C} \\
\mathrm{Ob}\end{array}$ & $\begin{array}{l}\text { Development } \\
\text { hold Estimate }\end{array}$ & \\
\hline RDT\&E & $\begin{array}{l}\$ 59,677.3 \\
\end{array}$ & $\$ 9,677.3$ & -- & $\$ 59,172.9$ \\
\hline Procurement & $266,665.8$ & $266,665.8$ & -- & $260,618.7$ \\
\hline Flyaway & -- & -- & -- & $226,216.1$ \\
\hline Recurring & -- & -- & -- & $202,475.0$ \\
\hline Non Recurring & -- & -- & -- & $23,741.1$ \\
\hline Support & -- & -- & -- & $34,402.6$ \\
\hline Other Support & -- & -- & -- & $180,30.9$ \\
\hline Initial Spares & -- & -- & -- & $16,371.7$ \\
\hline MILCON & $4,168.0$ & $4,168.0$ & -- & $3,701.9$ \\
\hline Acq O\&M & 0.0 & 0.0 & -- & 0.0 \\
\hline Total & $\$ 330,511.1$ & $\$ 330,511.1$ & N/A & $\$ 323,493.5$ \\
\hline
\end{tabular}

The F-35 program has become quite controversial, not only for its increasingly exorbitant costs, but also for serious questions about its ability to perform the roles envisioned for it. First, any engineered system that promises all things to all people, as the F-35 seemingly does, is more than likely not realistic in its claims or will demonstrate compromised performance in most, if not all, domains. That is, in order to meet what are often conflicting requirements, a requirement in one area must be compromised, to some degree, to satisfy a requirement in another area. In short, and even in the best light, the F-35 is arguably a "jack of all trades and master of none" and, in the combat arena, second place usually means you die.

The fighter operational requirements of the USAF, USN, Marines, and allied air forces all differ to varying degrees. This is only natural since the mission requirements of all these different military forces are somewhat different. Addressing these different mission requirements is the rationale behind the three primary models of the JSF, the F-35A, F-35B, and F-35C. However, there is another requirement imposed on the F-35 which states that these three models must maintain 80 percent commonality with each other (Lorell, 2013). Questions arise as to how effectively any of these models can address the requirements of a specific user while at the same time maintaining the design goal of 80 percent commonality between the airframes. In other words, to what degree must the

\footnotetext{
${ }^{26}$ The SAR is created by the Department of Defense annually for reporting the year-by-year status of major acquisition programs to Congress. This SAR covers the calendar year ending December 2013.
} 
performance requirements of any model of the F-35 be compromised to be able to simultaneously meet other, but different user requirements, such that 80 percent of the airframes of all three models remain the same? For example, imagine going to a car dealership and telling the salesman that you want to buy a single vehicle that performs like the most powerful and best handling sports car on the road, but also that this vehicle must be able to transport six adults in comfort and it must be able to readily haul large objects such as refrigerators, riding lawnmowers, motorcycles, and other bulky cargo. Also, this vehicle must obtain outstanding fuel economy, while at the same time being able to tow the family's large camping trailer or an off-shore fishing boat; and if they can throw in offroad, four-wheel drive capability, it'll be all the better. Also, somehow, this vehicle must be better at all these tasks than any competing vehicles, specialized or not, because second place is not an option. The salesman is liable to look at you as though you are just plain nuts, but many will tell you that this is essentially on the order of what is being asked of and promised by the maker of the F-35 - Lockheed Martin.

Pierre Sprey, a co-founding member of the so-called "fighter mafia" at the Pentagon and a co-designer of the highly successful F-16 Fighting-Falcon, ${ }^{27}$ is one of the F-35's staunchest critics. He calls the F-35 the product of "an exceptionally dumb piece of Air Force PR spin" and "inherently a terrible airplane" (Lomberg, 2014). Mr. Sprey says that the F-35 would likely lose a close-in aerial combat encounter to a well-flown MiG-21 - a 1950's Soviet second-generation fighter design. He contends that the F-35 in close-air combat doesn't stand a remote a chance of success against more modern Soviet/Russian fourth-generation designs such as the Mikoyan-Gurevich MiG-29/35 Fulcrum and the Sukhoi Su-27/30/33/35/37 Flanker series of fighter aircraft, or their Chinese equivalents (Lomberg, 2014). The idea that all modern air-to-air combat would be conducted at long range ${ }^{28}$ would be to repeat the erroneous ideas of the mid-1950s and, even in that realm, it's not clear that the F-35 would hold much, if any, advantage over its antagonists. Further, in a May 2013 article on the F-35 controversy, the Defense Industry Daily stated that the "F-35's explicit design goal has been stated as being the F-16's equal in air-to-air combat at a time when the F-16's future ability to survive in that arena is questioned" (Defense Industry Daily, 2013). Then, as if to give unintended credence to the F-35's critics, the Pentagon has lowered the performance requirements of the F-35 on at least a few occasions since it became obvious that the F-35 could not meet the requirements as originally specified (Axe, 2013).

Alternatively, there are pilots who have flown the F-35 who praise the flying qualities of the airplane; however, several of these pilots have vested interest is praising the airplane, such as being employees of Lockheed Martin, a partner company, or a pilot otherwise associated with the F-35 development. For example, a Marine F-35 test pilot stated that operational pilots should be "thrilled" with the performance of the F-35. He went on to describe the F-35s flight performance as being like that of the F/A-18, a fourth-generation fighter design (Majumdar, 2011). Assuming that the F-35 does, in fact, perform was well as the F/A-18, then one must ask that if the F-35 - a fifthgeneration design - is no better than the F/A-18 in performance, then why don't we just produce more F/A-18s and save a tremendous amount of money in the process? That is exactly what the governments of Canada and Australia have been debating (Defense Industry Daily, 2014; Air Power Australia, 2014). Both of those nations are current F/A-18 operators and if they decide to back out of the program, what will be the cost of implications for the remaining partner nations? To aggravate this situation, two more of the F-35's key partner nations - the UK and Italy - currently produce and operate the very high-performance Eurofighter (Typhoon). The Eurofighter's performance exceeds that of the F/A-18, which has led to both the UK and Italy debating the wisdom of the continuing with F-35 versus just producing more Eurofighters (Madslien, 2010; de Briganti, 2014). In fact, there are strong arguments being made internationally that buying the Eurofighter might be a wiser move, both economically and operationally, than buying the problem-plagued F-35 with its questionable performance and exorbitant costs (Defense Industry Daily, 2013).

A RAND study in 2013 found, during the F-35 development phase, that the three primary models - the F35A, F-35B, and F-35C - have migrated so far apart in actual design that the initial intent of having a single-base design is likely to prove more expensive than if the USAF, USN, and Marines had simply set out to design and develop separate aircraft to meet their specific operational requirements. Again, the initial goal for the F-35 was to have 80 percent of the airframe components in common for all three primary versions. Rand's evaluation of the

\footnotetext{
${ }^{27}$ Known in the fighter community as the "Viper."

${ }^{28}$ Beyond visual range.
} 
program determined that by 2008, the commonality had dropped to between 27 and 43-percent (Lorell, 2014); that is, the entire commonality premise of the F-35 program - the Joint Strike Fighter - has been violated and shown to be fleeting in concept.

The F-35 program was initiated in 2001. The program's costs are now estimated to be well over twice its initial cost estimates and the program is at least seven years behind schedule. Currently, under the latest revised schedule, the first F-35s are supposed to be operational by mid-2015, but the Government Accountability Office (GAO) is warning that may well not happen. Many of the development problems center on software development, which has been problematic since the outset of the program. Then, to make matters worse, in June 2014, a F-35 experienced an engine fire during takeoff at Eglin Air Force Base in Florida where operational testing of the F-35 was being conducted. That engine fire led to grounding the entire F-35 fleet. While such problems are not completely uncommon to new aircraft developments, especially developments as sophisticated and advanced as military fighter aircraft, this grounding came just as the bi-annual Royal International Air Tattoo (RIAT) at Farnborough, England ${ }^{29}$ was to commence. The grounding resulted in a no-show of the F-35 at Farnborough, likely leading to increased questioning of the wisdom of the already problem-plagued F-35 program. At a minimum, it certainly will add to the program managers' headaches.

Relations between the Pentagon and Lockheed Martin have been deteriorating over the last few years as a result of the ongoing schedule delays and cost overruns. Under political pressure, the Pentagon publically rebuked Lockheed-Marin in 2012, stating that it would no longer bail them out monetarily if current and new problems were not corrected. Lieutenant General Michael Bogdan, the Program Executive Officer for the F-35 Lightning II Joint Program Office, in describing the relationship between the Pentagon and Lockheed Martin, stated, "I'm on record after being in the job for only a month standing up and saying it was the worst relationship I had seen in my acquisition career." General Bogdan has made other comments that shine additional light on this relationship (Clark, 2012):

- " $\quad$ "Today, I am going to manage this program as if there is no more time and no more money."

- The Joint Program Office will "have to fundamentally change the way we do business with Lockheed Martin."

- $\quad$ "Long gone is the time where we will continue to pay for mistake after mistake after mistake."

- $\quad$ "Lockheed Martin is showing some improvements in producing this aircraft. Is it coming fast enough for us? No."

- "Are costs coming down as fast as we want them to? No."

- "We have an awful lot of software on this program; it scares me."

\section{DISCUSSION}

This is a mega defense program that has major implications for the country at large, the national and international economies, and our and our allies' national defense. Let's suppose you are a member of Lockheed Martin's executive management. What would you argue is the best way to address this situation? Do you pursue maximum profits in the interest of the stockholders, even at the expense of our national defense capabilities? If so, this could possibly end up costing lives because pilots are flying fighter aircraft that can't match the performance of their adversaries or because the fighter aircraft they are flying can't effectively neutralize the threats to other units of the US armed forces (e.g., threats to US ground forces), not to mention civilians on the home front who depend on and expect effective national defense. Or do you place national defense first and foremost and possibly cost Lockheed Martin a lot of money in the short term? If so, this could lead to you possibly losing your job. Remember, most performance reports tend to be rather myopic. Or, do you try to take a balanced approach, with a longer-term view and seek to work out a solution that, while maybe somewhat painful in the short term, stands a better chance of supporting long-term growth for the company and providing better weapon systems for our armed

\footnotetext{
${ }^{29}$ On even-numbered years the major international aerospace airshows are held at Farnborough, England, and on odd-numbered years at Paris, France. These airshows are where all the world's major aerospace manufacturers and developers come to demonstrate their products and seek international sales, both to government and commercial buyers. This includes military and civil aircraft, aircraft systems, and support equipment. It also includes various weapons systems. Doing well at these airshows is crucial to sales success.
} 
forces? That may sound easy, but it may prove to be a hard sell and even harder to implement. This is a real-world, ethics, management, and financial problem where solutions are evasive and each potential solution is fraught with problems of their own. This matter is also a proverbial political minefield. The following considerations should be taken into account when evaluating this program:

- The first responsibility of the US government is to provide for the common defense of the nation. With the exception of the F-22, America's current frontline fighter aircraft are designs of the late 1960s and early 1970s. Many of these aircraft have long ago exceeded their original expected service lives in terms of both years and flying hours (stress on an airframe). While a program of on-going upgrades and life-extension programs have kept these aircraft viable, technology has marched on and newer, more capable designs are sorely needed to meet current and anticipated future national defense requirements.

- The US economy, along with the global economies, has not been stellar since at least 2008. Real unemployment is at levels not seen since the Great Depression. The national debt has climbed to unprecedented levels and the US armed forces are scaling back in several areas to be able to continue operations. This is primarily due to a combination of reduced budgets and increasing operating costs. This means that pilots, for example, get far fewer training hours due to higher fuel and operating costs, which in turn can translate to potentially lower proficiency levels. Further, as a means of addressing reduced budgets and rising costs, the armed services are reducing the size of their forces to levels not seen since before America's involvement in World War II. This is depriving the military of highly-trained and experienced personnel, while adding to the roles of the unemployed looking for work.

- $\quad$ A significant part of our national defense capability is our technology base and experienced know-how. Maintaining that experienced technological base is essential to our national defense. This means that our defense industry must be maintained in some fashion, although some of it can be redirected to more civil applications since, in at least a few areas, the skills are the same.

- $\quad$ Cancelation of the F-35 project would likely lead to a major reduction in the size of Lockheed Martin's work force, both at the craftsman and professional levels. Such reductions in work forces would also likely occur at the partner firms, suppliers, and the infrastructure businesses surrounding the Lockheed Martin facilities. Often when defense and space contracts expire and are not renewed, or are cancelled, the surrounding communities essentially die and become relative ghost towns. There are several examples of this around the country. ${ }^{30}$ Cancelling the "largest defense program in the history of the mankind" cannot have anything but major economic impacts, domestically and internationally.

- If the F-35's performance is indeed inferior to anticipated enemy fighter aircraft, then we are putting our military men and women in an airplane with diminished chances of successful combat encounters. As previously mentioned, second place in combat means you likely die. Combat is a binary encounter in that you either win or you lose. This is aggravated by the reduced number of training hours that pilots will spend training in the cockpit, which will be a result of reduced DOD budgets and the high cost of the F-35 itself.

- If the cost of a military asset is too high, then the nation likely cannot afford to buy as many of these assets as defense planners determine are needed for adequate defense of the nation. Lockheed Martin's F-22 fighter is such an asset. The F-22 is a great performer, but the airplane simply costs too much for the USAF to be able to afford to buy the number of them really needed. The USAF has been filling the gap with updated legacy F-15 and F-16 aircraft, but that can't go on forever. The way the costs are climbing for the F-35, this F-22 situation is likely to be repeated with it as well.

- If the F-35 program is cancelled or altered in a major way, it will have major political, defense, and economic effects on our allies who are partnering with us in developing and fielding this airplane. What might this do for our relations with those nations, some of which are already strained?

- $\quad$ Does any politician or political party have the political stomach to terminate this program with a possible large loss of votes? On the other hand, how can they reconcile this with the taxpayers? Is there too much "face to save" in regard to this program?

\footnotetext{
${ }^{30}$ The communities in Florida's north Brevard County, near the Kennedy Space center and Cape Canaveral Air Force Station, have borne witness of this as various defense and space programs have come to completion with no follow-on programs or have been cancelled. Several of these communities are virtual ghost towns where many residential homes and commercial buildings have gone unsold, even at heavily discounted prices, for years.
} 
- $\quad$ The Lockheed Martin corporate management has a duty to the company's shareholders and to its other stakeholders. In properly addressing that duty, the Lockheed Martin management would seemingly like to not only address short-term profitability, but also provide for long-term profit sustainability. Lockheed Martin already has the stain of the "Deal of the Century" to contend with and the F-35 situation is shaping up to possibly eclipse even that scandal, or at least be perceived as eclipsing it. There are likely several politicians that can and will use the F-35 situation for their own political purposes and the resulting publicity will likely not bide well for Lockheed Martin. The current publicity is already somewhat lessthan-optimal.

\section{AUTHOR INFORMATION}

Michael P. Hughes is an associate professor of finance at Francis Marion University in Florence, South Carolina. Dr. Hughes holds a Ph.D. in finance, an MBA, and a BSET in operations. Dr. Hughes' research interests lie in financial markets, market microstructure, financial econometrics, fixed income securities, central banking, and government finance, to include defense finance. Prior to his being an academic, Dr. Hughes served for over 21 years in the US Air Force with F-4 and, later, F-15 fighter aircraft, and then in nuclear treaty monitoring. During his years in the air force, Dr. Hughes was involved in systems design, development, testing and evaluation, maintenance, and operations. Dr. Hughes is the son of a US Air Force fighter pilot and grew up in the air force. He has three sons of his own, two of which are career military officers. One of those sons is an AH-64D Apache pilot with the US Army.

\section{REFERENCES}

1. Aero News Network. (2013). "Report Says F-35 Is A 'Bad Deal' For The US Military.” Retrieved from http://www.aero-news.net/index.cfm?do=main.textpost\&id=75ed3801-6755-4a0b-a904-68bd4ffe7e11.

2. Archer, Megan. (2014). “Aviation fans crushed as it is confirmed F-35 fighter jet will NOT be flying at RIAT 2014." Wilts and Gloucestershire Standard. Retrieved from http:// www.wiltsglosstandard.co.uk/news/11333021.F_35_fighter_jet_will_NOT_be_flying_at_RIAT_2014/.

3. Air Power Australia. (2014). "Joint Strike Fighter.” Retrieved from http://ausairpower.net/ jsf.html.

4. Aviation Spectator. (2014). "C-5 Galaxy: Aircraft profile.” Retrieved from http:// www.aviationspectator.com/resources/aircraft-profiles/c-5-galaxy-aircraft-profile.

5. Axe, David. (2013). "Pentagon Downgrades Specs for Its Premier Stealth Jet — Again." Wired. Retrieved from http://www.wired.com/2013/02/pentagon-downgrades-jet-specs/.

6. Capaccio, Tony. (2013). "Lockheed F-35 Bad Deal as One Jet for All, Report Finds.” Bloomberg. Retrieved from http://www.bloomberg.com/news/2013-12-17/lockheed-f-35-bad-deal-as-one-jet-for-all-report-finds.html.

7. Cenciotti, David. (2013). "No way an F-35 will ever match a Typhoon fighter jet in aerial combat' Eurofighter test pilot says." The Aviationist. Retrieved from http:// theaviationist.com/2013/02/11/typhoonaerial-combat/.

8. Clark, Collin. (2012). 'F-35 Program's Relationship with Lockheed 'Worst I've Ever Seen' Says Gen. Bogdan.” Breaking Defense. Retrieved from http://breakingdefense.com/2012/09/ f-35-programsrelationship-with-lockheed-worst-ive-ever-seen/.

9. de Briganti, Giovanni. (2014). "Italy to Cut F-35 Buy, But Not Pull Out: Prime Minister." Defense Aerospace.com. Retrieved from http://www.defense-aerospace.com/article-view/feature/152466/italy-torevise,-cut-f_35-buy.html.

10. Defense Industry Daily. (2013). “The F-35's Air-to-Air Capability Controversy.” Retrieved from http://www.defenseindustrydaily.com/the-f-35s-air-to-air-capability-controversy-05089/.

11. ---. (2014). "Canada Preparing to Replace its CF-18 Hornets." Retrieved from http://www.defenseindustrydaily.com/Canada-Preparing-to-Replace-its-CF-18-Hornets-05739/.

12. Department of Defense. (2013). "Selected Acquisition Report (SAR): F-35 Joint Strike Fighter Aircraft (F35)." Scribd. Retrieved from http://www.scribd.com/doc/218876001/F-35-2013-SAR.

13. Estes, Adam Clark. (2013). "The U.S.'s Stealth Fighter Is Too Heavy and Slow, So the Pentagon Made Its Performance Tests Easier.” Motherboard. Retrieved from http:// motherboard.vice.com/blog/the-pentagonsnew-trillion-dollar-jet-is-a-garbage-can.

14. Francis, David. (2013). “The Pentagon’s Incredible \$1.5 Trillion Mistake.” The Fiscal Times. Retrieved 
from http://www.thefiscaltimes.com/Articles/2013/02/26/The-Pentagons-Incredible-1-5-Trillion-Mistake.

15. Freedberg, Sydney J., Jr., \& Colin Clark. (2014). "DoD Says F-35 Cost Drops Hill Aide Predicts Rise; PEO Slams Pratt \& Whitney.” Breaking Defense. Retrieved from http://breakingdefense.com/2014/04/dod-saysf-35-costs-drop-but-hill-aide-predicts-rise-peo-slams-pratt-whitney/.

16. Fuhr, Stephen. (2014). "The F-35 is totally unaffordable and can't do what was promised." The Province. Retrieved from http://blogs.theprovince.com/2014/06/16/stephen-fuhr-the-f-35-is-totally-unaffordable-andcant-do-what-was-promised/.

17. Germain, Scott E. (1999). Airliner Tech Series, Volume 1: Lockheed Constellation \& Super Constellation. North Branch, MN: Special Press Publishers and Wholesalers.

18. Gill, Kathy. (2014). "The Lockheed Bailout.” About.com US Politics. Retrieved from http://uspolitics.about.com/od/economy/ig/Financial-Bailouts-A-History/1971-Lockheed.htm.

19. GlobalSecurity.org. (2014). "F-35 Joint Strike Fighter (JSF) Lightning II.” Retrieved from http://www.globalsecurity.org/military/systems/aircraft/f-35.htm.

20. HistoryNet.com. (2014). “The Legendary Constellation.” Retrieved from http://www.historynet.com/thelegendary-lockheed-constellation.htm.

21. Jennings, Gareth. (2014). "Farnborough 2014: F-35 engine fire a 'one-off', though jets remain grounded." HIS Jane's 360. Retrieved from http://www.janes.com/article/40765/ farnborough-2014-f-35-engine-fire-aone-off-though-jets-remain-grounded.

22. Joebaugher.com. (1999). "The Deal of the Century." Retrieved from http:// www.joebaugher.com/ usaf_fighters/f104_11.html.

23. Kerrigan, Mary Beth. (2009). "Fiduciary Duty Obligations to Common Stockholders: Management Carveout Plans." Morse, Barnes-Brown, Pendleton. Retrieved from http://www.mbbp.com/resources/business/management_carve-out.html.

24. Lockheed Martin. (2014a). Retrieved from http://www.lockheedmartin.com/.

25. --- (2014b). "How the Constellation Became the Star of the Skies." Retrieved from http://www.lockheedmartin.com/us/100years/ stories/constellation.html.

26. Lomberg, Jason. (2014). “The F-35 was born of a 'dumb piece of Air Force PR spin'.” ECN. Retrieved from http://www.ecnmag.com/blogs/2014/06/f-35-was-born-dumb-piece-air-force-pr-spin.

27. Lorell, Mark A., et al. (2013). "Do Joint Fighter Programs Save Money?" Rand Corporation.

28. Lott, Maxim. (2014). "F-35 fighters plagued with delays, cost overruns, federal report says." Fox News. Retrieved from http://www.foxnews.com/tech/2014/04/03/f-35-fighters-plagued-with-delays-costoverruns-federal-report-says/.

29. Madslien, Jorn. (2010). "Eurofighter Typhoon squares up to F-35 challenge.” BBC. Retrieved from http://www.bbc.co.uk/news/business-10726346.

30. Majumdar, Dave. (2011). "F-35 Tests Proceed, Revealing F/A-18-Like Performance." Retrieved from http://www.defensenews.com/article/20110516/DEFSECT01/105160302/F-35-Tests-Proceed-Revealing-F18-Like-Performance.

31. Martin, David. (2014). "Is the F-35 worth it?" CBS News: 60 Minutes. Retrieved from http://www.cbsnews.com/news/f-35-joint-strike-fighter-60-minutes/.

32. McCaffrey, Bob. (2014). "The Aviator Howard Hughes." Retrieved from http:// www.aviatorhowardhughes.com/twa.htm.

33. McGarvey, Ronald G. (date?). "Assessment of Beddown Alternatives for the F-35." Rand Corporation.

34. Mehta, Aaron. (2013). "Pentagon grounds F-35 fleet over engine issues." USA Today. Retrieved from http://www.usatoday.com/story/news/nation/2013/02/22/pentagon-grounds-f-35-fleet/1940187/.

35. National Museum of the US Air Force. (2014a). "Lockheed C-130E Hercules." Retrieved from http://www.nationalmuseum.af.mil/factsheets/factsheet.asp?id=18724.

36. ---. (2014b). "Lockheed C-141C Starlifter 'Hanoi Taxi'.” Retrieved from http://www.nationalmuseum.af.mil/factsheets/factsheet.asp?id=3981.

37. ---. (2014c). “Lockheed F-80C Shooting Star.” Retrieved from http://www.nationalmuseum.af.mil/factsheets/factsheet.asp?id=290.

38. ---. (2014d). "Lockheed F-104C Starfighter." Retrieved from http://www.nationalmuseum.af.mil/factsheets/factsheet.asp?id=377.

$39 . \quad---$. (2014e). "Lockheed P-38L Lightning." Retrieved from http://www.nationalmuseum.af.mil/factsheets/factsheet.asp?id=495. 
40. ---. (2014f). “Lockheed T-33A Shooting Star.” Retrieved from http://www.nationalmuseum.af.mil/factsheets/factsheet.asp?id=366.

41. Osborn, Kris. (2014). "Royal Air Force Upgrades Tornado in Shadow of F-35.” DOD Buzz. Retrieved from http://www.dodbuzz.com/2014/07/16/royal-air-force-upgrades-tornado-in-shadow-of-f-35/.

42. Thompson, Mark. (2013). "The Most Expensive Weapon Ever Built.” Time. Retrieved from http://content.time.com/time/magazine/article/0,9171,2136312,00.html

43. U.S. Air Force. (2014). "Lieutenant General Christopher C. Bogdan.” Retrieved from http:// www.af.mil/AboutUs/Biographies/Display/tabid/225/Article/108398/lieutenant-general-christopher-cbogdan.aspx.

44. UPI. (2013). "More problems cited in F-35 JSF program.” Business News. Retrieved from http://www.upi.com/ Business_News/Security-Industry/2013/04/01/More-problems-cited-in-F-35-JSFprogram/UPI-41081364863839/.

45. Wikipedia. (2014a). "Deal of the Century." Retrieved from http://en.wikipedia.org/wiki/ Deal_of_the_century.

46. ---. (2014b). “Joint Strike Fighter program.” Retrieved from http://en.wikipedia.org/ wiki/Joint_Strike_Fighter.

$47 . \quad---$. (2014c). "Kelly Johnson (engineer).” Retrieved from http://en.wikipedia.org/ wiki/Kelly_Johnson_(engineer)

48. ---. (2014d). "Pierre Sprey.” Retrieved from http://en.wikipedia.org/wiki/Pierre_Sprey.

$49 . \quad$---. (2014e). "Lockheed bribery scandals.” Retrieved from http://en.wikipedia.org/wiki/ Lockheed_bribery_scandals.

50. ---. (2014f). "Lockheed C-130 Hercules.” Retrieved from http://en.wikipedia.org/wiki/C-130_Hercules.

51. ---. (2014g). "Lockheed C-141 Starlifter.” Retrieved from http://en.wikipedia.org/wiki/C-141.

52. ---. (2014h). "Lockheed Constellation.” Retrieved from http://en.wikipedia.org/wiki/ Lockheed_Constellation.

53. ---. (2014i). "Lockheed F-104 Starfighter.” Retrieved from http://en.wikipedia.org/ wiki/F-104.

54. ---. (2014j). "Lockheed L-1011 TriStar." Retrieved from http://en.wikipedia.org/ wiki/Lockheed_L-1011.

55. ---. (2014k). "Lockheed P-38 Lightning." Retrieved from http://en.wikipedia.org/wiki/P-38.

56. ---. (20141). "Lockheed P-80 Shooting Star.” Retrieved from http:// en.wikipedia.org/wiki/P80_Shooting_Star.

57. ---. (2014m). "Lockheed Martin Space Systems.” Retrieved from http://en.wikipedia.org/ wiki/Lockheed_Martin_Space_System.

58. ---. (2014n). "Lockheed Vega.” Retrieved from http://en.wikipedia.org/wiki/Lockheed_Vega.

59. ---. (2014o). "Skunk Works." Retrieved from http://en.wikipedia.org/wiki/Skunk_Works. 